\title{
UPAYA MENINGKATKAN PRESTASI BELAJAR IPA DENGAN MENGGUNAKAN METODE NUMBERED HEAD TOGETHER SISWA KELAS V SDN 2 KELAYU JORONG PADA MASA PANDEMI COVED-19 SEMESTER GANJIL TAHUN PELAJARAN 2021/2022
}

\author{
Oleh : \\ USWATUN HASANAH \\ SDN 2 KELAYU JORONG \\ Email : huswatun1975@gmail.com
}

\begin{abstract}
ABSTRAK
Jenis penelitian yang dilakukan apakah PTK atau PTS. Tujuan dari penelitian tindakan kelas (PTK) ini adalah untuk mengetahui sejauh mana peningkatkan Hasil belajar siswa pelajaran IPA dengan menerapkan Metode Numbered Head Together. Dalam penelitian tindakan kelas (PTK) ini dilakukan dalam 2 siklus, dari hasil tindakan yang dilakukan terbukti dapat meningkatkan Hasil belajar siswa dengan mencapai ketuntasan klasikal yang ditetapkan yaitu $85 \%$. Ketuntasan Klasikal $38.8 \%$ diperoleh pada siklus I, dapat meningkat pada siklus II menjadi $94.4 \%$. Dari segi aktivitas siswa juga ada peningkatan yaitu pada siklus I diperoleh kategori cukup aktif meningkat menjadi kategori aktif. Hasil penelitian tindakan ini menunjukkan bahwa penerapan Metode Metode Numbered Head Together dapat meningkatkan hasil belajar siswa pada pelajaran IPA dengan ketuntasan mencapai $94.4 \%$.
\end{abstract}

Kata Kunci : Hasil belajar, Metode Numbered Head Together.

\begin{abstract}
The type of research conducted is PTK or PTS. The purpose of this classroom action research (CAR) is to find out the extent to which students' learning outcomes in science have been increased by applying the Numbered Head Together Method. In this classroom action research (CAR), it is carried out in 2 cycles, from the results of the actions taken it is proven to be able to improve student learning outcomes by achieving the classical mastery that is set at $85 \% .38 .8 \%$ classical completeness obtained in the first cycle, can be increased in the second cycle to $94.4 \%$. In terms of student activity, there was also an increase, namely in the first cycle, the moderately active category increased to an active category. The results of this action research indicate that the application of the Numbered Head Together Method can improve student learning outcomes in science lessons with completeness reaching $94.4 \%$.
\end{abstract}

Keywords: Learning outcomes, Numbered Head Together Method. 


\section{LATAR BELAKANG}

Pembelajaran merupakan suatu proses intraksi dan komunikasi antar guru dan siswa dalam membahas suatu pengetahuan.Dalam setiap pembelajaran kami sebagai guru mengharapkan semua siswa yang kami bimbing dapat dengan aktif dan kreatif menerima pelajaran serta menguasai materi pelajaran yang nantinya dapat menghasilkan nilai yang memuaskan, tetapi tidak selamanya keinginan dan harapan ini dapat terwuju, karena banyaknya kendala dan kekurangan di saat pembelajaran berlangsung seperti halnya kegiatan yang pernah kami lakukan dengan berbagai macam cara dan metode tepatnya di kelas V SDN 2 Kelayu Jorong pada kegiatan pembelajaran IPA.

(Ardhana 1997) berpendapat bahwa kualitas proses dan produk pembelajaran belum memadai, lebih- lebih kalau dikaitkan dengan upaya mempersiapkan manusia Indonesia di masa depan. Hasil yang kurang memuaskan ini mungkin sebagian terjadi karena kekurang mampuan pembelajar ( teacher, trainer) dalam menyelenggarakan proses pembelajaran yang memenuhi tuntutan perkembangan, dan juga karena adanya cara pandang para siswa terhadap proses pembelajaran Mustaji, 2005;2).

Dalam hal keberhasilan pendidikan secara umum, banyak tergantung atas intraksi dari beberapa faktor pendidikan yang cakupannya lebih luas. Namun karena wawasan tentang pendidikan masyarakat terbatas, maka maju mundurnya pendidikan dibebankan kepada lembaga pendidikan itu sendiri, yang termasuk di dalamnya adalah guru.

Pada tahun ajaran 2021/2022 jumlah siswa kelas V SDN 2 Kelayu Jorong berjumlah 18 orang, kami menggunakan metode ceramah,siswa malah kebanyakan mengantuk bahkan tidur, kami menggunakan metode Tanya jawab, anak-anak malah kebanyakan diam, anak-anak kami beri tugas kelompok, anak-anak malah main-main, kami berikan tugas individu ,anak-anak malah kebingungan.

Mata pelajaran Bahasa Indonesia adalah salah satu mata pelajaran yang ada pada sekolah dasar dan tidak sedikit anakanak yang kesulitan untuk mempelajari Bahasa Indonesia khususnya pada materi mengarang. Hal ini di lihat dari hasil yang di peroleh,dari 18 orang siswa, sekitar 7 orang yang nilainya mencapai atau melebihi KKM, sedangkan 11 orang masih belum bias memenuhi nilai sesuai KKM

Kami berkesimpulan bahwa kurangnya perhatian/minat sisawa pada pembelajaran dikarenakan siswa lebih suka diam dari pada bertanya dan kurangnya pemahaman siswa dalam penguasaan materi sehingga hasil yang diharpkan tidak sesuai dengan tujuan pembelajaran. Hal ini terbukti dengan adanya siswa yang tidur dan main- main ketika pembelajaran sedang berlangsung dan terbukti pula pada setiap kali latihan soal pada akhir pokok pembahasan, siswa tidak dapat menjawab soal dengan benar sehingga siswa yang memperoleh nilai ideal hanya sekitar 7 orang.

Atas dasar inilah saya terdorong untuk melakukan perbaikan pembelajaran melalui Penelitian Tindakan Kelas (PTK) dengan upaya meningkatkan prestasi belajar IPA dengan menggunakan metode Numbered Head Togedher kelas V SDN 2 Kelayu Jorong pada masa pandemic coved-19 semester ganjil tahun pelajaran 2021/2022.

\section{KAJIAN PUSTAKA}

\section{Belajar dan Hasil Belajar}

a. Belajar

Belajar menurut Gagne (Mulyani Sumantri \& Johar Pertama, 1999: 16) belajar merupakan sejenis perubahan yang diperlihatkan dalam perubahan tingkah laku, yang keadaannya berbeda dari yang sebelum individu berada dalam situasi belajar dan sesudah melakukan tindakan yang serupa. Perubahan terjadi akibat adanya suatu pengalaman atau latihan.Berbeda dengan perubahan serta merta akibat reflek atau perilaku yang bersifat naluriah. Dari pendapat di atas ternyata belajar merupakan

Menurut Gagne dalam kutipan Martinis Yamin belajar merupakan kegiatan yang kompleks, dimana setelah belajar tidak hanya memilki pengetahuan, keterampilan, sikap dan nilai akan tetapi siswa harus mampu beradaptasi dengan lingkungan dan mengembangkan pemikiranya karena belajar proses kognitif, Martinis Yamin(2007:106). Selain itu belajar Menurut Watsot dalam kutipan Asri 
Budiningsih adalah proses interaksi antara stimulus dan respon, namun stimulus dan respon yang dimaksud harus berbentuk tingkah laku yang dapat diamati dan dapat diukur (Asri Budiningsih 2005:22). Sedangkan menurut ( Nana Sudjana 2008:28) definisi belajar adalah proses yang diarahkan kepada tujuan, proses berbuat melalui berbagai pengalaman. Belajar adalah proses melihat, mengamati, memahami sesuatu.

Dari beberapa definisi belajar di atas dapat disimpulkan bahwa belajar adalah suatu kegiatan interaksi antar individu untuk memperoleh perubahan kemampuan, perubahan tingkah laku yang didapat dari pengalaman dan akan bertahan lama.

Ciri- ciri belajar adalah:

1. Perubahan perilaku relatif permanent. Ini berarti bahwa perubahan tingkah laku yang terjadi karena belajar untuk waktu tertentu akan tetap atau tidak berubah ubah. Tetapi perubahan tersebut tidak akan terpancang seumur hidup.

2. Sesuatu yang memperkuat itu akan memberikan semangat atau dorongan untuk mengubah tingkah laku. Drs. H. Baharudin, M. Pd. I dan Esa Nur Wahyuni, M. Pd. Dalam bukunya Teori Belajar dan Pembelajaran, 2008 : 13-17.

b. Hasil Belajar

Hasil belajar merupakan proses dalam diri individu yang berinteraksi dengan lingkungan untuk mendapatkan perubahan dalam perilakunya. Perubahan itu diperoleh melalui usaha (bukan karena kematangan), menetap dalam waktu yang relatif lama dan merupakan hasil pengalaman. (Nana Sudjana, 2009: 3) menjelaskan penilaian hasil belajar adalah proses pemberian nilai terhadap hasilhasil belajar yang dicapai oleh siswa dengan kreteria tertentu. Tingkah laku sebagai hasil belajar dalam pengertian luas mencangkup tiga ranah: kognitif, afektif dan psikomotorik. Oleh sebab itu, dalam penilaian hasil belajar, perencanaan tujuan instruksioanal yang berisi rumusan kemampuan dan tingkah laku yang di inginkan dikuasai siswa menjadi unsur penting sebagai dasar dan acuan penialian.

Faktor-faktor yang mempengaruhi hasil belajar yaitu :

1. Faktor Internal (dari dalam individu yang belajar).

Faktor yang mempengaruhi kegiatan belajar ini lebih ditekankan pada faktor dari dalam individu yang belajar. Adapun faktor yang mempengaruhi kegiatan tersebut adalah faktor psikologis, antara lain yaitu : motivasi, perhatian, pengamatan, tanggapan dan lain sebagainya.

2. Faktor Eksternal (dari luar individu yang belajar).

Pencapaian tujuan belajar perlu diciptakan adanya sistem lingkungan belajar yang kondusif. Hal ini akan berkaitan dengan faktor dari luar siswa. Adapun faktor yang mempengaruhi adalah mendapatkan pengetahuan, penanaman konsep dan keterampilan, dan pembentukan sikap.

3. Hasil belajar yang diperoleh siswa adalah sebagai akibat dari proses

Belajar yang dilakukan oleh siswa, harus semakin tinggi hasil belajar yang diperoleh siswa. Proses belajar merupakan penunjang hasil belajar yang dicapai siswa, diambil dalam Nana Sudjana dalam http :// techonly13 wordpress. com/2009/07/04/pengertian-hasilbelajar.

\section{Metode Numbered Head Together}

\section{a. Pengertian Metode Numbered Head} Together

Numbered Head Together ( NHT) atau penomoran berpikir bersama menurut Herdian (2009) mengatakan bahwa model pembelajaran tipe NHT merupakan salah satu tipe pembelajaran kooperatif yang menekankan pada struktur khusus yang dirancang untuk mempengaruhi pola interaksi siswa dan memiliki tujuan untuk meningkatkan penguasaan akademik.

Sri Rahayu (2009) berpendapat bahwa Numbered head together adalah suatu Model pembelajaran yang lebih mengedepankan kepada aktivitas siswa dalam mencari, mengolah, dan melaporkan informasi dari berbagai 
sumber yang akhirnya dipresentasikan di depan kelas.

\section{b. Kelebihan Metode Numbered Head Together}

1. Mengembangkan rasa tanggung jawab.

2. Menggalang kerjasama dan kekompakan dalam kelompok.

3. Membuat siswa aktif mencari bahan untuk menyelesaikan tugasnya.

4. Siswa dapat bertanya kepada kelompok lain.

5. Membuat siswa lebih berani mengemukakan pendapat dan bertan kepada kelompok lain.

c. Kekurangan Metode Numbered Head Together

1. Bagi siswa yang kurang pandai akan berpikir pasif

2. Tugas kelompok akan dikerjakan oleh orang tertentu atau siswa yang rajin dan pintar

3. Sulit memberi tugas yang sesuai dengan perbedaan individu.

\section{d. Langkah - Langkah Metode} Numbered Head Together

1. Penomoran

2. Pengajuan Pertanyaan

3. Berfikir Bersama

4. Pemberian Jawaban

\section{Penelitian Yang Relevan}

Sebuah PTK dikatakan relevan jika salah satu variabel bebasnya sama. Nama Peneliti: Majaya yusuf (2013), Judul PTK: Peningkatan Hasil Belajar Siswa Melalui Metode Numbered Head Together Pada Pelajaran PKn di Kelas IV SD Negeri 2 Ogotua, Tujuan penelitian Meningkatkan Hasil Belajar Siswa Melalui Metode Numbered Head Together Pada Pelajaran PKn di Kelas IV SD Negeri 2 Ogotua, Hasil Penelitiantian: Siklus I diperoleh ketuntasan klasikal yang meningkat tiap siklus yaitu siklus I $68,57 \%$, siklus II $100 \%$. Begitu pula persentase daya serap individu siswa, siklus I pertemuan pertama $68,14 \%$, pertemuan kedua $72,00 \%$ dan siklus ke II 77,57\%. Berdasarkan indicator kinerja, maka dapat disimpulkan bahwa model pembelajaran kooperatif tipe Numbered Head Together yang dilakukan dalam pembelajaran dapat meningkatkan hasil belajar PKn pada siswa kelas IV SDN 2 Ogotua.

\section{METODE PENELITIAN}

\section{Setting Penelitian}

a. Subyek Penelitian

Subyek penelitian adalah siswa kelas

V SD Negeri 2 Kelayu Jorong kecamatan Selong kabupaten Lombok Timur tahun pelajaran 2021/2022 yang berjumlah 18 siswa dan terdiri atas 10 siswa laki-laki dan 8 siswa perempuan dengan usia rata-rata 11 tahun, karena masa covid-19 sehingga subyek penelitian diambil 18 siswa.

\section{b. Tempat dan Waktu Penelitian}

Penelitian ini dilaksanakan di kelas V SD Negeri 2 Kelayu Jorong kecamatan Selong kabupaten Lombok Timur yang merupakan tempat tugas peneliti. Penelitian ini dilaksanakan dengan menggunakan dua siklus, dengan setiap siklusnya dilaksanakan 2 kali pertemuan. Penelitian ini dilaksanakan selama kurang lebih tiga bulan, yaitu mulai Bulan Oktober sampai dengan Desember 2021, dengan jadwal kegiatan sebagai berikut:

\section{c. Jenis Penelitian}

Jenis Penelitian yang diambil adalah Penelitian Tindakan Kelas (PTK), yaitu penelitian yang mengupayakan perbaikan proses pembelajaran yang hasilnya akan memeberikan dampak bagi peningkatan aktivitas belajar siswa yang bermuara pada prestasi belajar.

\section{d. Siklus I}

1) Perencanaan Tindakan

2) Perencanaan Tindakan

3) Observasi dan Evaluasi

4) Refleksi

\section{e. Siklus II}

Perencanaan dan pelaksanaan tahapan pada siklus 2 tidak berbeda dengan tahapan pada siklus 1 , hanya saja kekurangan pada siklus 1 diharapkan dapat diperbaiki pada siklus 2 .

\section{Prosedur Penelitian}

Dalam penelitian ini peneliti menggunakan desain dengan model (Suharsimi Arikunto, 2008: 16) 


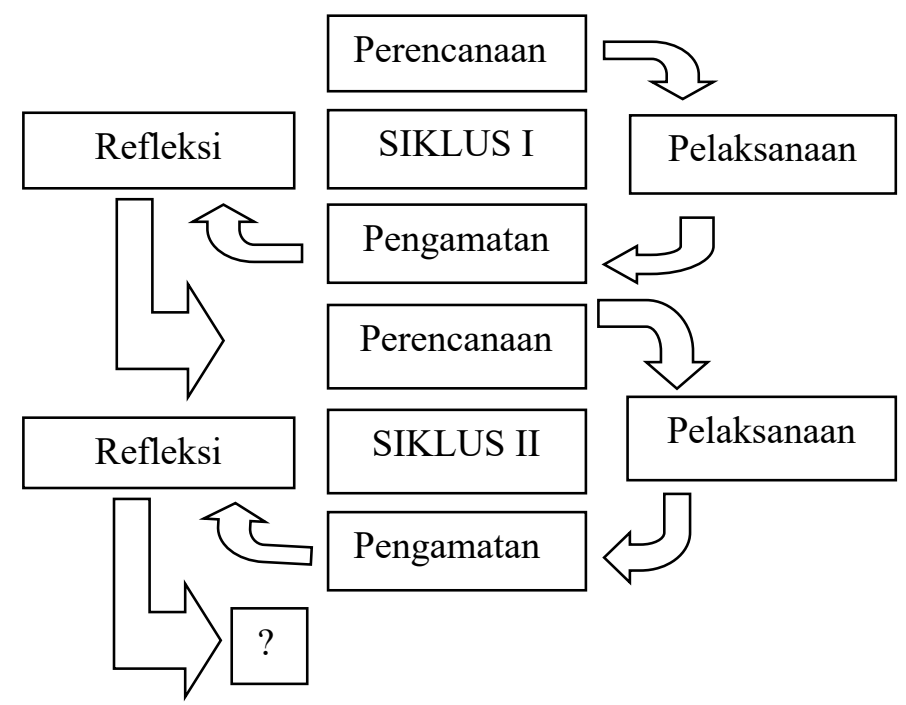

Penelitian ini dilaksanakan dengan menggunakan du siklus, dengan setiap siklusnya dilaksanakan 2 kali pertemuan yang meliputi:
a. Perencanaan Tindakan
b. Pelaksanaan
c. Observasi dan Evaluasi
d. Refleksi

\section{Tenik Pengumpulan Data}

a. Instrumen pelaksanaan pembelajaran

b. Instrumen pengumpulan data
1. Dokumentasi
2. Observasi
3. Tes evaluasi pada setiap siklus

\section{Teknik Analisa Data}
a. Data aktivitas siswa
b. Data tes hasil belajar

\section{Hasil Penelitian dan Pembahasan}

Pada bab ini akan dikemukakan analisis data yang diperoleh dari hasil observasi dan hasil evaluasi pada setiap siklus yang telah direncanakan. Data yang diperolah berupa data kuantitatif dari hasil evaluasi dan data kualitatif yang dikumpulkan dari hasil observasi. Data kuantitatif yang diperoleh dari hasil evaluasi akan memberikan jawaban mengenai keberhasilan atau tidaknya proses pembelajaran dengan menerapkan metode Numbered Head Togedher yang diukur dengan ketuntasan belajar secara klasikal. Data kualitatif diperoleh dari hasil observasi yang akan memberikan gambaran tentang aktivitas siswa maupun aktivitas guru yang dilakukan oleh observer pada

setiap pertemuan pelaksanaan proses pembelajaran. Berikut ini akan disajikan data hasil penelitian pada setiap siklus yang telah direncanakan.

I. Siklus I

\section{a. Perencanaan}

Pada tahap ini yang akan dilakukan adalah kegiatan membuat rencana pelaksanaan pembelajaran, terlampir.

\section{b. Pelaksanaan Tindakan}

Dalam tahap pelaksanaan
tindakan dilaksanakan pembelajaran sesuai dengan rencana pelaksanaan pembelajaran yang telah dibuat. Untuk dapat menyesuaikan rencana pelaksanaan pembelajaran dalam penyampaian materi, termasuk didalamnya pembelajaran dengan menggunakan metode Numbered Head Togedher dilaksanakan dalam 3 kali pertemuan, dimana 2 kali pertemuan untuk penyampaian materi dan 1 kali pertemuan untuk evaluasi.

\section{c. Observasi dan Evaluasi}

\section{Hasil Observasi}

dari hasil pengamatan yang dilakukan oleh observer yang dilakukan oleh rekan guru peneliti dengan mengisi lembar observasi aktivitas guru dan aktivitas siswa untuk merekam jalannya proses pembelajaran. Dari hasil observasi dan pengamatan yang dilakukan, didapatkan bahwa proses pembelajaran belum sesuai dengan yang diharapkan karena masih 
terdapat kekurangan-kekurangan baik dari pihak guru sendiri maupun dari pihak siswa.
Berdasarkan hasil observasi terhadap aktivitas siswa setelah dianalisa diperoleh data sebagai berikut:

Tabel 4.1. Hasil Observasi Aktivitas Siswa Pada Siklus I

\begin{tabular}{|c|c|c|c|c|c|c|c|c|c|}
\hline \multirow{2}{*}{ Pertemuan } & \multicolumn{6}{|c|}{ Jumlah skor yang tampak } & \multirow{2}{*}{$\begin{array}{c}\Sigma \text { Skor } \\
\text { aktivitas }\end{array}$} & \multirow{2}{*}{$\begin{array}{l}\text { Rata-rata } \\
\text { Aktivitas } \\
\end{array}$} & \multirow{2}{*}{ Kategori } \\
\hline & 1 & 2 & 3 & 4 & 5 & 6 & & & \\
\hline Pertama & 4,3 & 2,7 & 3,3 & 3,3 & 2,7 & 3,3 & 19,6 & 3,3 & $\begin{array}{l}\text { Cukup } \\
\text { Aktif }\end{array}$ \\
\hline Kedua & 4,3 & 3,0 & 3,3 & 3,7 & 3,0 & 3,7 & 21,0 & 3,5 & $\begin{array}{l}\text { Cukup } \\
\text { Aktif }\end{array}$ \\
\hline
\end{tabular}

Dari tabel di atas dapat dilihat bahwa aktivitas belajar siswa pada siklus I pertemuan 1 adalah 3,3 dengan kategori cukup aktif dan pertemuan 2 adalah 3,5 kategori Cukup Aktif. Oleh karena itu maka aktivitas siswa pada siklus berikutnya masih perlu ditingkatkan.

\section{Evaluasi Hasil Belajar}

Data lengkap tentang prestasi atau hasil belajar siswa pada siklus 1 berdasarkan hasil evaluasi pada siklus 1 setelah dianalisis diperoleh data sebagai berikut:

Tabel 4.2: Hasil Evaluasi Belajar Siswa Pada Siklus I

\begin{tabular}{|c|l|l|l|l|l|}
\hline No. & \multicolumn{1}{|c|}{ Nama Siswa } & L/P & Skor & Nilai & $\begin{array}{c}\text { Tuntas/ Tidak } \\
\text { Tuntas } \\
\text { (KKM=62) }\end{array}$ \\
\hline 1. & Arif Febrian Hadi & L & 10 & 50 & Tidak Tuntas \\
\hline 2. & Ayuni Apriana & P & 16 & 80 & Tuntas \\
\hline 3. & Anisa Fitri & P & 15 & 75 & Tuntas \\
\hline 4. & Bunga Canggih & P & 10 & 50 & Tidak Tuntas \\
\hline 5. & Beni Rahmandani & L & 11 & 55 & Tidak Tuntas \\
\hline 6. & Hidayatul Rizqi & P & 14 & 70 & Tuntas \\
\hline 7. & Lukita Sari & P & 14 & 70 & Tuntas \\
\hline 8. & Muh.Ibrahim Ismail Muqmin & L & 11 & 55 & Tidak Tuntas \\
\hline 9. & M. Abdul Rosyid & L & 9 & 45 & Tidak Tuntas \\
\hline 10. & Marlina & P & 12 & 60 & Tidak Tuntas \\
\hline 11. & M. Asis Sopianto & L & 9 & 45 & Tidak Tuntas \\
\hline 12. & M. Zuhairi & L & 9 & 45 & Tidak Tuntas \\
\hline 13. & Muhammad Afif Fahmi Alrsyi & L & 12 & 60 & Tidak Tuntas \\
\hline 14. & Nanang Satria Kurniawan & L & 12 & 60 & Tidak Tuntas \\
\hline 15. & Rija Rulhadi & L & 8 & 40 & Tidak Tuntas \\
\hline 16. & Rizki Ziadil Farid & L & 13 & 65 & Tuntas \\
\hline 17. & Siti Ayu Kalsum & P & 16 & 80 & Tuntas \\
\hline 18. & Sukma Yanisa Aura & P & 14 & 70 & Tuntas \\
\hline & Jumlah Nilai & & & 1075 & \\
\hline & Nilai Rata-rata & & & 59,4 & \\
\hline & Jumlah Siswa Yang Tuntas & & & 7 & \\
\hline & Persentase Ketuntasan Klasikal & & & $38,8 \%$ & \\
\hline
\end{tabular}

Dari tabel di atas dapat dilihat bahwa ketuntasan belajar yang dicapai siswa adalah $38,8 \%$ dengan nilai rata-rata 59,4. Hasil ini belum mencapai ketuntasan belajar secara klasikal sehingga pembelajaran dilanjutkan ke siklus berikutnya.

d. Refleksi

Berdasarkan analisis hasil observasi pada siklus I, jumlah siswa 
yang tuntas masih 38,8 \% berarti masih dibawah standar minimum yakni $85 \%$. Hasil tersebut belum mencapai hasil yang diharapkan, untuk itu peneliti melanjutkan ke siklus berikutnya. Dalam siklus I ini terdapat kekurangan-kekurangan yang perlu untuk dipehatikan dan diperbaiki pada kegiatan siklus II.

\section{Hasil Penelitian Siklus II}

Proses pembelajaran pada siklus II diawali dengan pemberian umpan balik dari hasil evaluasi yang diberikan. Oleh karena itu, sebelum berdiskusi guru menghimbau agar siswa tidak ada yang ngobrol, mengganggu temannya yang lain, dan tidak ada siswa yang diam memperhatikan teman-temannya, demikian juga pembagian tugas dalam setiap kelompok harus lebih jelas sehingga siswa dapat melaksanakan tugasnya masingmasing.

\section{a. Perencanaan}

Pada tahap ini yang akan dilakukan adalah kegiatan membuat rencana pelaksanaan pembelajaran

\section{b. Pelaksanaan Tindakan}

Dalam tahap pelaksanaan tindakan dilaksanakan kegiatan pembelajaran sesuai dengan rencana pelaksanaan pembelajaran yang telah dibuat. Untuk dapat menyesuaikan rencana pelaksanaan pembelajaran dalam penyampaian materi, termasuk didalamnya pembelajaran dengan menggunakan Numbered Head Togedher dilaksanakan dalam 3 kali pertemuan, dimana 2 kali pertemuan untuk penyampaian materi dan 1 kali pertemuan untuk evaluasi.

\section{c. Observasi dan Evaluasi}

\section{Hasil Observasi}

Hasil observasi diperoleh dari hasil pengamatan yang dilakukan oleh observer yang dilakukan oleh rekan guru peneliti dengan mengisi lembar observasi aktivitas guru dan aktivitas siswa untuk merekam jalannya proses pembelajaran. Pada saat pembelajaran siklus II telah dilakukan perbaikan, dari analisis hasil observasi aktivitas siswa pada siklus II didapat bahwa aktivitas siswa tergolong aktif dalam setiap pertemuan. Hal ini dapat dilihat pada tabel skor aktivitas siswa mengalami peningkatan dari pertemuan pertama ke pertemuan ke dua, seperti yang terlihat pada tabel dibawah ini.

Tabel 4.3. Hasil Observasi Aktivitas Siswa Pada Siklus II

\begin{tabular}{|l|l|l|l|l|l|l|l|l|l|}
\hline \multirow{2}{*}{ Pertemuan } & \multicolumn{6}{|c|}{$\begin{array}{c}\Sigma \text { Sumlah skor yang tampak } \\
\text { aktivitas }\end{array}$} & $\begin{array}{c}\text { Rata-rata } \\
\text { Aktivitas }\end{array}$ & \multirow{2}{*}{ Kategori } \\
\cline { 2 - 7 } & 1 & 2 & 3 & 4 & 5 & 6 & \\
\hline Pertama & 4,3 & 3,7 & 3,7 & 4,3 & 4,0 & 4,0 & 24 & 4,0 & Aktif \\
\hline Kedua & 4,7 & 3,7 & 3,7 & 4,3 & 4,0 & 4,7 & 25,1 & 4,2 & Aktif \\
\hline
\end{tabular}

Dari tabel diatas dilihat bahwa aktivitas siswa pada siklus II untuk pertemuan 1 adalah 4 dan pertemuan 2 adalah 4,2.

\section{Evaluasi Hasil Belajar}

Data lengkap tentang prestasi belajar siswa pada siklus II berdasarkan hasil evaluasi pada siklus II setelah dianalisis diperoleh data sebagai berikut :

Tabel 4.4: Hasil belajar yang diperoleh siswa pada siklus II

\begin{tabular}{|c|l|l|l|l|l|}
\hline No. & \multicolumn{1}{|c|}{ Nama Siswa } & L/P & Skor & Nilai & $\begin{array}{c}\text { Tuntas/ Tidak } \\
\text { Tuntas } \\
(\text { Kkm=62) }\end{array}$ \\
\hline 1. & Arif Febrian Hadi & L & 16 & 80 & Tuntas \\
\hline 2. & Ayuni Apriana & P & 18 & 90 & Tuntas \\
\hline 3. & Anisa Fitri & P & 19 & 95 & Tuntas \\
\hline 4. & Bunga Canggih & P & 14 & 70 & Tuntas \\
\hline 5. & Beni Rahmandani & L & 15 & 75 & Tuntas \\
\hline
\end{tabular}




\begin{tabular}{|c|l|l|l|l|l|}
\hline 6. & Hidayatul Rizqi & $\mathrm{P}$ & 17 & 85 & Tuntas \\
\hline 7. & Lukita Sari & $\mathrm{P}$ & 16 & 80 & Tuntas \\
\hline 8. & Muh.Ibrahim Ismail Muqmin & $\mathrm{L}$ & 15 & 75 & Tuntas \\
\hline 9. & M. Abdul Rosyid & $\mathrm{L}$ & 13 & 65 & Tuntas \\
\hline 10. & Marlina & $\mathrm{P}$ & 16 & 80 & Tuntas \\
\hline 11. & M. Asis Sopianto & $\mathrm{L}$ & 15 & 75 & Tuntas \\
\hline 12. & M. Zuhairi & $\mathrm{L}$ & 15 & 75 & Tuntas \\
\hline 13. & Muhammad Afif Fahmi Alrsyi & $\mathrm{L}$ & 14 & 70 & Tuntas \\
\hline 14. & Nanang Satria Kurniawan & $\mathrm{L}$ & 16 & 80 & Tuntas \\
\hline 15. & Rija Rulhadi & $\mathrm{L}$ & 12 & 60 & Tidak Tuntas \\
\hline 16. & Rizki Ziadil Farid & $\mathrm{L}$ & 15 & 75 & Tuntas \\
\hline 17. & Siti Ayu Kalsum & $\mathrm{P}$ & 18 & 90 & Tuntas \\
\hline 18. & Sukma Yanisa Aura & $\mathrm{P}$ & 18 & 90 & Tuntas \\
\hline & Jumlah Nilai & & & 1410 & \\
\hline & Nilai Rata-Rata & & & 78,3 & \\
\hline & Jumlah Siswa Yang Tuntas & & & 17 & \\
\hline & Persentase Ketuntasan Klasikal & & & $94,4 \%$ & \\
\hline
\end{tabular}

Hasil evaluasi yang diperoleh pada siklus II ini mencapai tingkat $94,4 \%$ jadi sudah dapat dikatakan tuntas, untuk itu tidak perlu lagi diadakan pembelajaran pada siklus berikutnya dengan ketuntasan belajar yang sudah dicapai, dengan demikian pembelajaran dengan menerapkan Numbered Head Togedher dikatakan dapat meningkatkan hasil / prestasi belajar IPA

\section{d. Refleksi}

Dari hasil observasi aktivitas siswa pada siklus II, kegiatan pembelajaran sudah dapat berjalan dengan baik, dimana hasil observasi aktivitas siswa dengan hasil pertemuan 1 kategori cukup aktifdan pertemun 2 dengan kategori Aktif. Dari hasil analisis terhadap hasil evaluasinya terjadi peningkatan rata-rata kelas maupun persentase ketuntasan secara klasikal sudah mencapai/melebihi $85 \%$ artinya sudah $85 \%$ atau lebih siswa sudah mencapai nilai hasil ulangan sebesar KKM atau melebihi KKM yang ditentukan. Oleh karena itu penelitian ini dihentikan sampai siklus II sesuai dengan perencanaan.

\section{PEMBAHASAN}

Penelitian tindakan kelas ini dilaksanakan sebagai upaya untuk meningkatkan Prestasi belajar IPA pada siswa kelas $\mathrm{V}$ dengan melaksanakan pembelajaran dengan menerapkan/menggunakan Numbered Head Togedher di SDN 2 Kelayu Jorong Tahun Pembelajaran 2021/2022.

Berdasarkan hasil analisis data pada tiap siklus, terlihat bahwa hasil dari siklus I ke siklus II mengalami peningkatan. Pada pelaksanaan pembelajaran dan hasil analisis data siklus I, untuk aktivitas siswa diperoleh kategori cukup aktif dan aktivitas siswa pada siklus II diperoleh aktivitas siswa dengan kategori aktif

Terkait dengan hasil ulangan pada siklus I dan II dapat dilihat rinciannya dibawah ini

Tabel 4.5 : Ringkasan Hasil Evaluasi Pada Siklus I

\begin{tabular}{|l|l|c|}
\hline No & \multicolumn{1}{|c|}{ Uraian } & Hasil \\
\hline 1 & Nilai Terendah & 45 \\
\hline 2 & Nilai Tertinggi & 80 \\
\hline 3 & Rata-rata & 59,4 \\
\hline 4 & Jumlah siswa yang tuntas & 7 \\
\hline 5 & Jumlah siswa yang ikut tes & 18 \\
\hline 6 & Persentase yang tuntas & $38,8 \%$ \\
\hline
\end{tabular}

Sedangkan pada siklus II hasilnya sebagai berikut : 
Tabel 4.6 : Ringkasan Hasil Evaluasi Pada Siklus II

\begin{tabular}{|l|l|c|}
\hline No & \multicolumn{1}{|c|}{ Uraian } & Hasil \\
\hline 1 & Skor Terendah & 60 \\
\hline 2 & Skor Tertinggi & 90 \\
\hline 3 & Rata-rata & 78,3 \\
\hline 4 & Jumlah siswa yang tuntas & 17 \\
\hline 5 & Jumlah siswa yang ikut tes & 18 \\
\hline 6 & Persentase yang tuntas & $94,4 \%$ \\
\hline
\end{tabular}

Setelah melihat kedua tabel hasil evaluasi dari siklus I dan II dimana nilai yang mereka peroleh sudah mencapai tingkat ketuntasan belajar. Dan melebihi tingkat ketuntasan belajar secara klasikal yaitu $85 \%$. Penelitian tindakan kelas ini dilaksanaan sebagai upaya untuk meningkatkan aktivitas dan prestasi atau hasil belajar IPA pada materi Gangguan Peredaran Darah melalui penerapan metode Numbered Head Togedher. Dimana penelitian ini dilakukan dalam dua siklus.

\section{E. Kesimpulan}

Berdasarkan hasil penelitian dan pembahasan diatas, dapat di simpulkan bahwa Penerapan Numbered Head Together dapat meningkatkan aktivitas dan hasil atau prestasi belajar siswa di SDN 2 Kelayu Jorong. Peningkatan tersebut dapat dilihat dari perolehan nilai skor aktivitas siswa, dan nilai rata-rata kelas serta tingkat ketuntasan secara klasikal pada tiap siklus mengalami peningkatan baik pada siklus I maupun siklus II. Dan dari hasil penelitian dan pembahasan dapatlah kami simpulkan Penerapan Numbered Head Together dapat meningkatkan hasil atau prestasi belajar IPA pada siswa kelas V SDN 2 Kelayu Jorong Tahun Pelajaran 2021/2022

\section{DAFTAR PUSTAKA}

Ari Kunto 2006, Penelitian tindakan bebas, Jakarta: Bumi Aksara.

Baharuddin 2008, Teori Belajar dan Pembelajaran, Yogyakarta: Ar-Ruzz Media Grup.
Budiningsih, Asri 2005, Belajar dan Pembelajaran, Jakarta: Rineka Cipta.

Martini Yamin 2007, Strategi dan Metode Dalam Model Pembelajaran,Jakarta: Gaung Persada Press.

Martini Yamin 2007, Strategi Pembelajran Berbasis Kompetensi, Jakarta: Gaung Persada Press.

Mulyani Sumantri, Johar Permana 2001, Strategi Belajar Mengajar, Bandung : CV. Maulana.

Nana Sudjana 2008, Dasar- Dasar Proses Belajar Mengajar, Bandung: Sinar Baru.

Suyono \& Harianto 2011, Belajar dan Pembelajaran, Surabaya: Unesa

Trianto 2007, Model Pembelajaran Terpadu dalam Teori dan Peraktik, Jakarta: Prestasi Pustaka

Trianto 2009, Mendesain Model Pembelajaran Inovaif Progresif, Jakarta: Prenada Media Grup. 